\title{
Tofacitinib as a Steroid-Sparing Therapy in Pulmonary Sarcoidosis, An Open-Label Prospective Proof-of-Concept Study
}

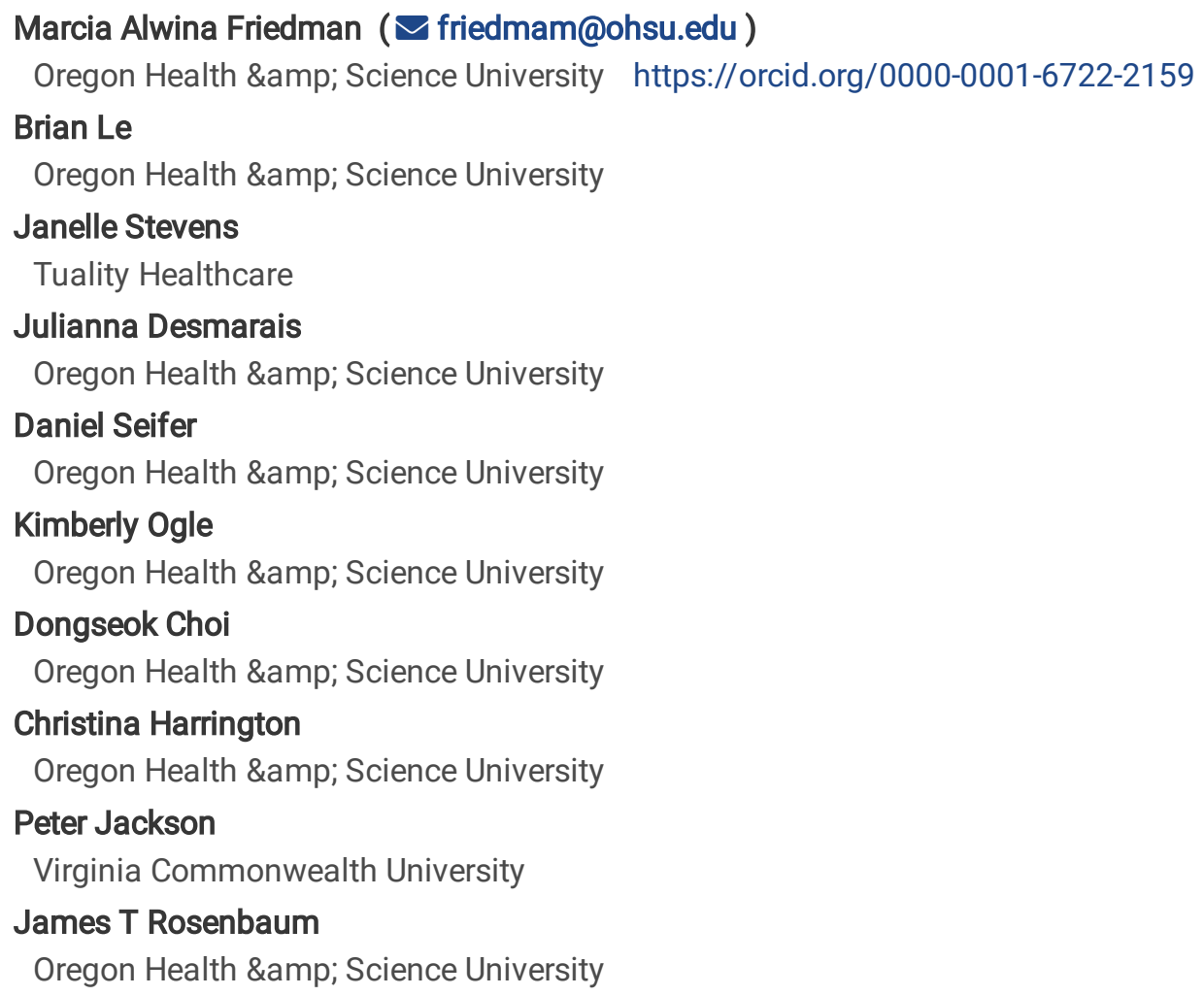

\section{Research Article}

Keywords: sarcoidosis, Janus kinase inhibitors, pulmonary sarcoidosis

Posted Date: February 26th, 2021

DOl: https://doi.org/10.21203/rs.3.rs-249391/v1

License: (c) (i) This work is licensed under a Creative Commons Attribution 4.0 International License. Read Full License

Version of Record: A version of this preprint was published at Lung on April 7th, 2021. See the published version at https://doi.org/10.1007/s00408-021-00436-8. 


\section{Abstract}

This is a prospective, open-label, proof-of-concept study of tofacitinib, a Janus kinase inhibitor, as a steroid sparing therapy in corticosteroid-dependent pulmonary sarcoidosis. 5 patients with corticosteroid-dependent pulmonary sarcoidosis were treated with tofacitinib $5 \mathrm{mg}$ twice daily. The primary endpoint was a $\geq 50 \%$ reduction in corticosteroids at week 16 with no worsening in pulmonary function or respiratory symptoms. $60 \%$ of patients $(3 / 5)$ met the primary endpoint. One patient was lost to follow up prior to steroid taper, and another was withdrawn due to worsening of known neurosarcoidosis. The three patients who met the primary endpoint each tapered to $\leq 5 \mathrm{mg} /$ day prednisone, respiratory symptoms improved, and spirometry remained stable. In this proof-of-concept study, the addition of a JAK-inhibitor allowed $60 \%$ of patients with pulmonary sarcoidosis to successfully taper corticosteroids. JAK-inhibitors are a promising therapy for pulmonary sarcoidosis, which require further investigation in randomized trials.

Trial Registration: clinicaltrials.gov NCT03793439; registered Jan 4, 2019

\section{Introduction}

Sarcoidosis is an inflammatory disorder of unclear etiology. The vast majority of patients develop pulmonary involvement, which may include interstitial lung disease, lymphadenopathy, granulomatous nodules, airway disease, and pulmonary hypertension [1]. The mainstay of treatment is corticosteroids; however, corticosteroids have numerous side effects, reduce quality of life in sarcoidosis patients [2], and relapses are common when attempting to taper [3]. While treatment guidelines are not well established, patients who are unable to taper corticosteroids due to progressive or relapsing pulmonary symptoms are candidates for steroidsparing therapy $[4,5]$.

Our group was the first to contend that sarcoidosis is a STAT-1 mediated disease [6]. The transcriptomic analyses of peripheral blood, lung, lymph node, and skin tissue of patients with sarcoidosis consistently shows upregulation of interferon, STAT1, and STAT1-regulated genes [6-9]. Lymph node granulomas from patients with sarcoidosis express an increase in phosphorylated STAT1 protein [6].

In a direct extension of these data, several case reports and 1 case series have shown improvement of primarily cutaneous sarcoidosis treated with the Janus protein tyrosine kinase (JAK) inhibitors [9-14]. However, pulmonary disease is the most common reason for treatment of sarcoidosis [15]. Little is known about the effect of JAK-inhibitors on pulmonary sarcoidosis, and prospective studies with pulmonary endpoints are lacking. The purpose of this prospective pilot study is to determine whether tofacitinib (a preferential JAK-1 and JAK-3 inhibitor) may be an effective steroid-staring therapy in pulmonary sarcoidosis.

\section{Methods}

Study Design and Patients: This was a 16-week open-label proof-of-concept study of tofacitinib as a steroid-sparing agent in corticosteroid-dependent pulmonary sarcoidosis. This study was registered at clinicaltrials.gov (NCT03793439) and approved by the Oregon Health \& Science University institutional review board (IRB 00017902). Inclusion criteria included: 1) meeting World Association for Sarcoidosis and other Granulomatous Disorders (WASOG) definition of pulmonary sarcoidosis [16], 2) histology consistent with sarcoidosis, 3) a forced vital capacity (FVC) $>50 \%$, and 4) symptoms or disease progression requiring a stable dose of 15-30 mg/day prednisone (or equivalent corticosteroids) for $\geq 4$ weeks prior to enrollment. Steroid dependent disease was defined by the need for steroids to control disease progression or symptoms but did not require evidence of pulmonary dysfunction on pulmonary function testing. In addition, all patients had a history of failed attempts to taper their corticosteroids to lower doses, and had been recommended for steroid-sparing therapy by their treating physicians. Exclusion criteria included the use of an immunosuppressive drug other than methotrexate in the preceding 8 weeks, history of malignancy, or opportunistic infection in the last 6 months, among others. (Full inclusion/exclusion criteria given in Online Resource 1.)

Treatment: Tofacitinib $5 \mathrm{mg}$ twice daily was given orally. After four weeks on tofacitinib, corticosteroids were tapered according to a preset protocol. (Online Resource 2) 
Assessments: Chest x-ray and diffusion capacity of lungs for carbon monoxide (DLCO) were evaluated at baseline and week 16. Spirometry, safety labs, adverse events, WASOG organ involvement, and the Saint George Respiratory Questionnaire $(S G R Q)[17,18]$ were monitored monthly. An analysis of RNA expression at baseline and week 16 was planned; however, after a preliminary analysis of two patients did not find significant changes, further gene expression analyses were not performed. (Online Resource 3)

Endpoints: The primary endpoint was a $\geq 50 \%$ reduction in corticosteroids at week 16 with no significant worsening in pulmonary function (>15\% decline in FVC or FEV1 relative to baseline) or respiratory symptoms measured by the SGRQ. Patients were withdrawn from the study if they developed worsening sarcoidosis in any other organ system, or required a prednisone increase to more than $30 \mathrm{mg} /$ day prednisone. Patients who met the primary endpoint were invited to enroll in a 1-year extension. During the 1year extension respiratory symptoms and adverse events were monitored; other disease monitoring was per treating physician.

Statistical Analysis: This study had a pre-specified definition of success: at least $60 \%(3 / 5)$ of patients meeting the primary endpoint. If a patient withdrew prior to week 16 , the last recorded values of spirometry and SGRQ were compared to baseline. However, if a patient withdrew prior to attempting steroid taper, spirometry and SGRQ measures were not included in the final analysis. An intention-to-treat spirometry and SGRQ analysis of all patients is available as Online Resource 4.

\section{Results}

Patients: Between May of 2019 and March of 2020, five patients were enrolled (Figure 1). Baseline characteristics are shown in Table 1. All patients had biopsy proven sarcoidosis; 2 by parenchymal lung, 2 by lymph node, and 1 by skin biopsy. All had evidence of at least one type of thoracic involvement on cross-sectional imaging: 1 with interstitial disease, 4 with pulmonary nodularity, and 3 with hilar/mediastinal lymphadenopathy. Two patients had extrapulmonary disease (Table 1).

Patients required an average of $19 \mathrm{mg} /$ day prednisone (range $15-25 \mathrm{mg} /$ day) and had been treated with prednisone for an average of 14.8 months (range 7-36 months) prior to the start of the trial. One patient took methotrexate $10 \mathrm{mg} /$ week for 2 months and stopped it at the start of the trial due to a perceived lack of benefit; another had previously failed methotrexate and mycophenolate mofetil; no patients were taking other immunosuppressive medications during the trial. All patients had a history of failing to taper corticosteroids any lower than their baseline dose due to disease flares, and all patients' treating physicians recommended initiating corticosteroid-sparing therapy. Baseline QuantiFERON, HIV, hepatitis B, and hepatitis C serologies were unremarkable.

Efficacy Assessments: This study met the predetermined proof-of-concept definition of success with 3 out of 5 patients (60\%) reaching the primary endpoint. One patient was lost to follow up prior to steroid taper (abruptly moved out of state 1 month after beginning the trial.) One patient was withdrawn due to worsening neurologic sarcoidosis (details available as Online Resource 5); this patient's pulmonary sarcoidosis remained well controlled.

Pulmonary function was stable for all patients, with all variance within the established $10 \%$ margin of inter-test variability. SGRQ scores improved in all categories over the course of the study by clinically significant margins. Chest x-rays improved for 2 patients and were stable for 2 patients. (Figure 2)

The three patients who met the primary endpoint (patients 1, 3, and 4 in Figure 2) all enrolled in the 1-year extension study. During the 1-year extension study all three patients tapered fully off corticosteroids (Figure 2) with no disease relapse. (Online Resource 6)

Adverse Events: There were two serious adverse events. The first was the worsening of neurosarcoidosis in patient 5, which required escalation of glucocorticoids and subsequent withdrawal from the study (detailed in Online Resource 5.) Secondly, during the 2week post-study monitoring period, patient 5 (who was withdrawn from the study due to worsening neurosarcoidosis) developed cellulitis requiring hospitalization. The cellulitis occurred while on prednisone $30 \mathrm{mg} / \mathrm{day}, 10$ days after the last dose of tofacitinib, and 9 days after starting infliximab $5 \mathrm{mg} / \mathrm{kg}$. Given the short half-life of tofacitinib, the investigators determined that the adverse event was more likely due to infliximab and prednisone rather than study drug. A full description of adverse events is available as Online Resource 5.

\section{Discussion}


There are currently no approved steroid-sparing therapies for sarcoidosis. The lung is the most commonly affected organ in sarcoidosis and treating patients with pulmonary disease is an important and unmet need. To our knowledge, this is the first prospective study of a JAK-inhibitor as a steroid-sparing agent in pulmonary sarcoidosis. 3 of 5 patients met the primary endpoint; all 3 were all able to taper fully off prednisone during the 1-year extension. One patient was withdrawn due to a flare of neurologic sarcoidosis-though this patient's pulmonary disease remained well controlled. It is possible that different organ systems in sarcoidosis require either higher doses, longer treatment durations, or entirely different medications. Based on these small results, neurologic sarcoidosis may need to be evaluated separately in future studies. A preliminary analysis of changes in whole blood JAK-STAT mediated genes was not significant-this is most likely due to significant corticosteroid use at baseline.

The strengths of this study include its prospective design, inclusion of patients with longstanding refractory disease, close monitoring of spirometry, respiratory symptoms, and chest imaging, and its focus on pulmonary disease, which is the most common indication for the treatment of sarcoidosis. The limitations of this study include its small size, lack of placebo or active drug (methotrexate) control, inclusion of only one woman and one African American patient, and loss to follow up of 1/5 patients. Metrics of glucocorticoid toxicity and global quality of life were also not included due to the small size and short duration of this study. Moving forward, a randomized, placebo-controlled multi-center study is necessary to further investigate JAK-inhibitors for pulmonary sarcoidosis.

\section{Declarations}

Funding: This is an investigator-initiated study with expenses paid by Pfizer. The pharmaceutical company played no role in the interpretation of data or the writing of this report.

Funding also including NIH grants R01 EY020249, R01 EY026572, P30 EY010572, KL2TR002370, and 3T32HL094294-08S1. Funding was also provided by an unrestricted grant from Research to Prevent Blindness, the Grandmaison Fund for Autoimmunity Research, the William and Mary Bauman Foundation, the Stan and Madelle Rosenfeld Family Trust, and the OHSU Wheels Up Program.

Conflicts of interest/Competing interests: JTR consults for Gilead, Abbvie, UCB, Roche, Santen, Corvus, Celldex, Affibody, Keyverna, Horizon, and Novartis.

Ethics approval: This study was approved by the Oregon Health \& Science University institutional review board (IRB 00017902) and was performed in accordance with the ethical standards as laid down in the 1964 Declaration of Helsinki and its later amendments.

Consent to participate: Informed consent was obtained from all individual participants included in the study.

Consent for publication: Participants provided informed consent for publication of this study.

Availability of data and material: Not applicable.

Code availability: Not applicable.

Authors' contributions: JTR conceived of the study. JTR, MAF, JS, KO, and PJ designed the study. MAF, BL, KO, JD, DS, and JTR collected the clinical data. JTR, MAF, JS, PJ, MAF, BL, JD, and DS analyzed the clinical data. CH extracted RNA and performed RNA sequencing. DC analyzed transcriptomic data. MAF and BL wrote the first draft of the manuscript. All authors substantially contributed to this work, all authors critically revised this manuscript for important intellectual contact, all authors approve the version to be publish, and all authors agree to be accountable for all aspects of the work in ensuring that questions related to the accuracy or integrity of any part of the work are appropriately investigated.

ACKNOWLEDGEMENTS: We wish to acknowledge the OHSU Massively Parallel Sequencing Shared Resource and the Gene Profiling Shared Resource, which performed all RNA extraction and sequencing for this work; Manny Rodriguez who assisted with the laboratory sample processing; and Puthyda Keath who assisted with patient coordination for this study. We additionally wish to thank the patients who participated in this study. 


\section{References}

1. Baughman RP, Teirstein AS, Judson MA, Rossman MD, Yeager H Jr, Bresnitz EA, DePalo L, Hunninghake G, lannuzzi MC, Johns CJ, McLennan G, Moller DR, Newman LS, Rabin DL, Rose C, Rybicki B, Weinberger SE, Terrin ML, Knatterud GL, Cherniak R, Case Control Etiologic Study of Sarcoidosis research g (2001) Clinical characteristics of patients in a case control study of sarcoidosis. Am J Respir Crit Care Med 164 (10 Pt 1):1885-1889. doi:10.1164/ajrccm.164.10.2104046

2. Judson MA, Chaudhry H, Louis A, Lee K, Yucel R (2015) The effect of corticosteroids on quality of life in a sarcoidosis clinic: the results of a propensity analysis. Respir Med 109(4):526-531. doi:10.1016/j.rmed.2015.01.019

3. Gottlieb JE, Israel HL, Steiner RM, Triolo J, Patrick H (1997) Outcome in sarcoidosis. The relationship of relapse to corticosteroid therapy. Chest 111(3):623-631. doi:10.1378/chest.111.3.623

4. Korsten P, Strohmayer K, Baughman RP, Sweiss NJ (2016) Refractory pulmonary sarcoidosis - proposal of a definition and recommendations for the diagnostic and therapeutic approach. Clin Pulm Med 23(2):67-75. doi:10.1097/CPM.0000000000000136

5. Spagnolo P, Rossi G, Trisolini R, Sverzellati N, Baughman RP, Wells AU (2018) Pulmonary sarcoidosis. Lancet Respir Med 6(5):389-402. doi:10.1016/S2213-2600(18)30064-X

6. Rosenbaum JT, Pasadhika S, Crouser ED, Choi D, Harrington CA, Lewis JA, Austin CR, Diebel TN, Vance EE, Braziel RM, Smith JR, Planck SR (2009) Hypothesis: sarcoidosis is a STAT1-mediated disease. Clin Immunol 132(2):174-183. doi:10.1016/j.clim.2009.04.010

7. Zhou T, Casanova N, Pouladi N, Wang T, Lussier Y, Knox KS, Garcia JGN (2017) Identification of Jak-STAT signaling involvement in sarcoidosis severity via a novel microRNA-regulated peripheral blood mononuclear cell gene signature. Sci Rep 7(1):4237. doi:10.1038/s41598-017-04109-6

8. Koth LL, Solberg OD, Peng JC, Bhakta NR, Nguyen CP, Woodruff PG (2011) Sarcoidosis blood transcriptome reflects lung inflammation and overlaps with tuberculosis. Am J Respir Crit Care Med 184(10):1153-1163. doi:10.1164/rccm.201106$11430 \mathrm{C}$

9. Damsky W, Thakral D, Emeagwali N, Galan A, King B (2018) Tofacitinib Treatment and Molecular Analysis of Cutaneous Sarcoidosis. N Engl J Med 379(26):2540-2546. doi:10.1056/NEJMoa1805958

10. Damsky W, Thakral D, McGeary MK, Leventhal J, Galan A, King B (2019) Janus kinase inhibition induces disease remission in cutaneous sarcoidosis and granuloma annulare. J Am Acad Dermatol. doi:10.1016/j.jaad.2019.05.098

11. Scheinberg M, Maluf F, Wagner J (2020) Steroid-resistant sarcoidosis treated with baricitinib. Ann Rheum Dis. doi:10.1136/annrheumdis-2020-217271

12. Wei JJ, Kallenbach LR, Kreider M, Leung TH, Rosenbach M (2019) Resolution of cutaneous sarcoidosis after Janus kinase inhibitor therapy for concomitant polycythemia vera. JAAD Case Rep 5(4):360-361. doi:10.1016/j.jdcr.2019.02.006

13. Damsky W, Young BD, Sloan B, Miller EJ, Obando JA, King B (2020) Treatment of Multiorgan Sarcoidosis With Tofacitinib. ACR Open Rheumatol 2(2):106-109. doi:10.1002/acr2.11112

14. Kerkemeyer KL, Meah N, Sinclair RD (2020) Tofacitinib for cutaneous and pulmonary sarcoidosis: A case series. J Am Acad Dermatol. doi:10.1016/j.jaad.2020.10.016

15. Baughman RP, Judson MA, Teirstein A, Yeager H, Rossman M, Knatterud GL, Thompson B (2006) Presenting characteristics as predictors of duration of treatment in sarcoidosis. QJM 99(5):307-315. doi:10.1093/qjmed/hcl038

16. Judson MA, Costabel U, Drent M, Wells A, Maier L, Koth L, Shigemitsu H, Culver DA, Gelfand J, Valeyre D, Sweiss N, Crouser E, Morgenthau AS, Lower EE, Azuma A, Ishihara M, Morimoto S, Tetsuo Yamaguchi T, Shijubo N, Grutters JC, Rosenbach M, Li HP, Rottoli P, Inoue Y, Prasse A, Baughman RP, Organ Assessment Instrument Investigators TW (2014) The WASOG Sarcoidosis Organ Assessment Instrument: An update of a previous clinical tool. Sarcoidosis Vasc Diffuse Lung Dis 31(1):19-27

17. Lo KH, Donohue J, Judson MA, Wu Y, Barnathan ES, Baughman RP, Sarcoidosis TI (2020) The St. George's Respiratory Questionnaire in Pulmonary Sarcoidosis. Lung 198(6):917-924. doi:10.1007/s00408-020-00394-7

18. Jones PW, Quirk FH, Baveystock CM (1991) The St George's Respiratory Questionnaire. Respir Med 85 Suppl B:25-31; discussion 33 - 27. doi:10.1016/s0954-6111(06)80166-6

Page $5 / 9$ 


\section{Tables}

Table 1

Baseline characteristics are shown as an average for all five patients, and individual data for each patient is shown. DMARD:

disease modifying anti-rheumatic drug, MTX: methotrexate, MMF: mycophenolate mofetil, ILD: interstitial lung disease, LAD: lymphadenopathy, DMARDs: disease modifying antirheumatic drugs; FEV1: forced expiratory volume in 1 second, FVC: forced vital capacity, DLCO: diffusion capacity for carbon monoxide, EBUS: endobronchial ultrasound

\begin{tabular}{|c|c|c|c|c|c|c|}
\hline & Average (range) & Patient 1 & Patient 2 & Patient 3 & Patient 4 & Patient 5 \\
\hline Age (years) & $40.8(35-50)$ & 37 & 35 & 43 & 39 & 50 \\
\hline Sex & Male (4) & Male & Male & Female & Male & Male \\
\hline Ethnicity & $\begin{array}{l}\text { Caucasian (4) } \\
\text { African American } \\
\text { (1) }\end{array}$ & Caucasian & Caucasian & Caucasian & $\begin{array}{l}\text { African } \\
\text { American }\end{array}$ & Caucasian \\
\hline $\begin{array}{l}\text { Months since } \\
\text { sarcoid } \\
\text { diagnosis }\end{array}$ & $33(9-60)$ & 48 & 24 & 9 & 60 & 24 \\
\hline $\begin{array}{l}\text { WASOG: } \\
\text { Highly } \\
\text { probably (HP) } \\
\text { At least } \\
\text { probably } \\
\text { (ALP) } \\
\text { Possible (P) }\end{array}$ & $\begin{array}{l}\text { Lung: HP (4); } \\
\text { ALP (4) } \\
\text { Skin: ALP (2) } \\
\text { Extra-thoracic } \\
\text { lymph nodes: } \\
\text { ALP (2) } \\
\text { Bone-Joint: P (1) } \\
\text { Spleen: ALP (1) } \\
\text { Calcium-Vitamin } \\
\text { D: ALP (1) } \\
\text { Nervous system: } \\
\text { HP (1) }\end{array}$ & Lung: ALP & Lung: HP; ALP & Lung: HP; ALP & $\begin{array}{l}\text { Lung: HP } \\
\text { Extra-thoracic } \\
\text { lymph nodes: } \\
\text { ALP } \\
\text { Skin: ALP } \\
\text { Joint: P }\end{array}$ & $\begin{array}{l}\text { Lung: HP; } \\
\text { ALP } \\
\text { Skin: ALP } \\
\text { Bone-Joint: } \\
\text { P } \\
\text { Spleen: ALP } \\
\text { Calcium- } \\
\text { Vitamin D: } \\
\text { ALP } \\
\text { Nervous } \\
\text { system: HP }\end{array}$ \\
\hline $\begin{array}{l}\text { Prednisone } \\
\text { dose } \\
\text { (mg/day) }\end{array}$ & $19(15-25)$ & 20 & 25 & 15 & 20 & 15 \\
\hline $\begin{array}{l}\text { Duration of } \\
\text { steroid use } \\
\text { prior to trial } \\
\text { (months) }\end{array}$ & $14.8(7-36)$ & 36 & 12 & 10 & 7 & 9 \\
\hline $\begin{array}{l}\text { DMARDs tried } \\
\text { (outcome) }\end{array}$ & $\begin{array}{l}\operatorname{MTX}(2) \\
\operatorname{MMF}(1)\end{array}$ & $\begin{array}{l}\text { MTX } 10 \\
\text { mg/week } \\
\text { x } 2 \\
\text { months } \\
\text { (no } \\
\text { benefit) }\end{array}$ & None & None & None & $\begin{array}{l}\text { MTX } \\
\text { (intolerance), } \\
\text { MMF (no } \\
\text { benefit) }\end{array}$ \\
\hline $\begin{array}{l}\text { Pulmonary } \\
\text { sarcoidosis } \\
\text { characteristics }\end{array}$ & $\begin{array}{l}\text { ILD (1) } \\
\text { Nodules (4) } \\
\text { Hilar/mediastinal } \\
\text { LAD (3) }\end{array}$ & ILD & $\begin{array}{l}\text { Nodules, } \\
\text { hilar/mediastinal } \\
\text { LAD }\end{array}$ & $\begin{array}{l}\text { Nodules, } \\
\text { hilar/mediastinal } \\
\text { LAD }\end{array}$ & $\begin{array}{l}\text { Nodules, } \\
\text { hilar/mediastinal } \\
\text { LAD }\end{array}$ & Nodules \\
\hline $\begin{array}{l}\text { Tissue } \\
\text { confirmation }\end{array}$ & $\begin{array}{l}\text { Lung biopsy (2) } \\
\text { Lymph node (2) } \\
\text { Skin (1) }\end{array}$ & $\begin{array}{l}\text { EBUS left } \\
\text { lower lobe }\end{array}$ & $\begin{array}{l}\text { EBUS right hilar } \\
\text { lymph node }\end{array}$ & $\begin{array}{l}\text { EBUS right } \\
\text { middle lobe }\end{array}$ & $\begin{array}{l}\text { Skin punch } \\
\text { biopsy }\end{array}$ & $\begin{array}{l}\text { Excisional } \\
\text { biopsy iliac } \\
\text { lymph node }\end{array}$ \\
\hline $\begin{array}{l}\text { Pulmonary } \\
\text { function (\% } \\
\text { predicted) }\end{array}$ & $\begin{array}{l}\text { FEV1: } 78.4(28- \\
113) \\
\text { FVC: } 86.6(55- \\
\text { 122) } \\
\text { DLCO: } 89.2(68- \\
\text { 105) }\end{array}$ & $\begin{array}{l}\text { FEV1: } 28 \\
\text { FVC: } 57 \\
\text { DLCO: } 95\end{array}$ & $\begin{array}{l}\text { FEV1: } 88 \\
\text { FVC: } 91 \\
\text { DLCO: } 105\end{array}$ & $\begin{array}{l}\text { FEV1: } 103 \\
\text { FVC: } 108 \\
\text { DLCO: } 100\end{array}$ & $\begin{array}{l}\text { FEV1: } 113 \\
\text { FVC: } 122 \\
\text { DLCO: } 68\end{array}$ & $\begin{array}{l}\text { FEV1: } 60 \\
\text { FVC: } 55 \\
\text { DLCO: } 78\end{array}$ \\
\hline
\end{tabular}




\section{Figure 1: Flow-chart of patient recruitment and dropout}

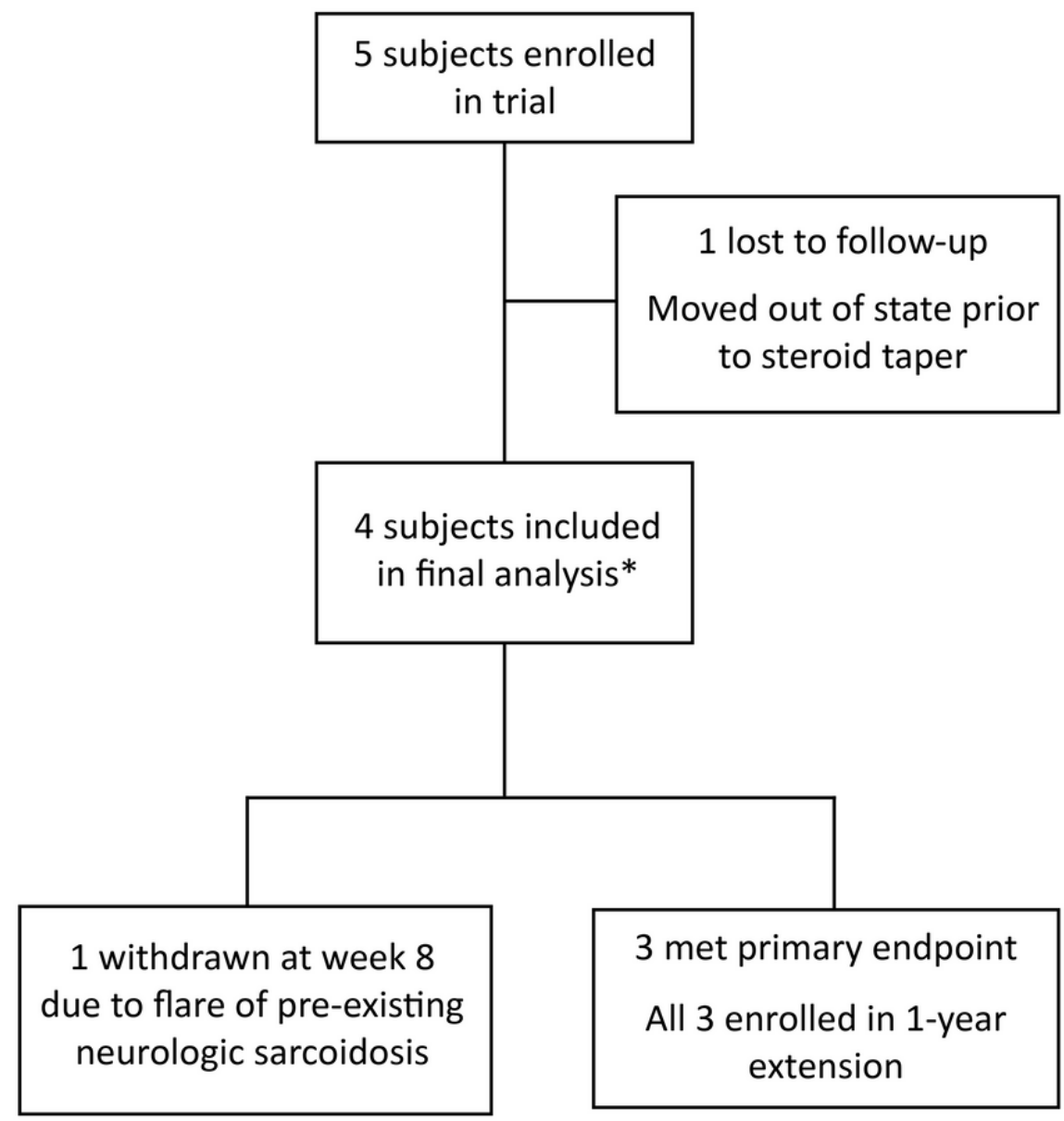

*5 subjects included in assessment of adverse events

\section{Figure 1}

Flowchart of patient recruitment and dropout. 5 patients were screened and enrolled in the study. One was lost to follow up at week 4 due to an unexpected move out of state; this patient was lost to follow up prior to steroid taper. 4 patients tapered prednisone and were included in the final analysis. 
Figure 2: Clinical Data
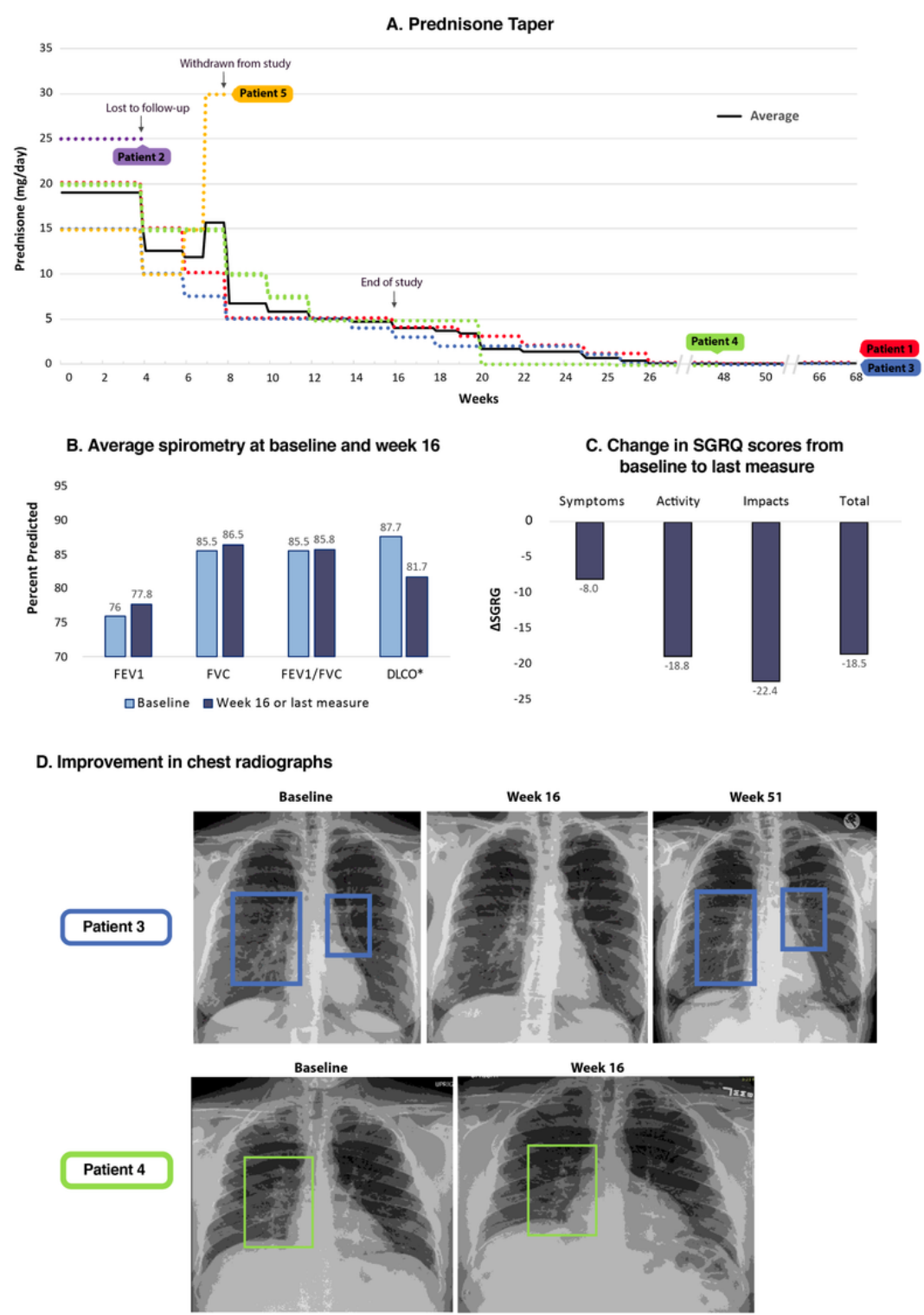

\section{Figure 2}

Clinical data. Prednisone taper is shown for all five patients; the remainder of clinical data includes only the four patients who attempted prednisone taper. A. Prednisone was tapered according to a specified protocol, Patient 2 was lost to follow up at week 4, and Patient 5 experienced worsening neurologic sarcoidosis requiring increased prednisone and ultimately withdrawal from the study. 3 patients met the primary endpoint and tapered to $\leq 5 \mathrm{mg} /$ day. All three tapered off prednisone during the 1-year extension; 2 completed the 1-year extension and Patient 4's extension study is ongoing. B. Pulmonary function was stable for all patients given established $10 \%$ between-test margin of variability for spirometry measurement. *DCLO is only shown for 3 patients, as this was done at baseline and week 16. C. Saint George Respiratory Questionnaire (SGRQ) scores all improved during the trial; a clinically significant difference for SGRQ is 4 units, thus all SGRQ changes were clinically significant. D) Chest radiographs from two patients whose radiographic findings improved during the study; patient 1 had a repeat chest x-ray at week 51 (during extension) showing further improvement. FEV1: forced expiratory volume in 1 second, FVC: forced vital capacity, DLCO: diffusion capacity for carbon monoxide.

\section{Supplementary Files}

This is a list of supplementary files associated with this preprint. Click to download. 
- ESM1.pdf

- ESM2.pdf

- ESM3.pdf

- ESM4.pdf

- ESM5.pdf

- ESM6.pdf

- ESM7.pdf 